\title{
Model Pembelajaran Meaningful Learning
}

\author{
Luthfi Rahman
}

Program Studi Pendidikan Fisika, Fakultas Keguruan Dan Ilmu Pendidikan, Universitas Siliwangi

Jl. Siliwangi No. 24, Kahuripan, Kec. Tawang, Tasikmalaya

Email : 182153060@student.unsil.ac.id

\begin{abstract}
Abstrak : Penelitian ini bertujuan untuk : Mengetahui metode pembelajaran meaningful learning, Belajar Bermakna, Penerapan pembelajaran, Pendekatan Metode Pembelajaran, Langkah-langkah belajar, Metode yang digunakan dalam penelitian ini adalah literasi (studi pustaka) dengan mengkaji beberapa sumber yang berkaitan dengan model pembelajaran Meaningful Learning.
\end{abstract}

KATA KUNCI : Meaningful Learning

Abstrack: This study aims to: Knowing the method of meaningful learning, meaningful learning, application of learning, approach to learning methods, learning steps, the method used in this study is literacy (library study) by examining several sources related to the Meaningful Learning learning model.

Key Word : Meaningful Learning

A. Pendahuluan

Kebutuhan inovasi pembelajaran sangat diperlukan sebagai dampak perkembangan seluruh aspek pada abad 21. Pada abad 21 terjadi pergeseran pembelajaran berpusat pada siswa dari sebelumnya yang berpusat pada pendidik (O'Malley \& Fierce, 2015). Pembelajaran yang berorientasi pada siswa yang mengarah pada pendidikan komperhensif (Yuwentin, dkk., 2020; Doyan, dkk., 2018). Pergeseran paradigma belajar abad 21 tidak terkecuali pada pembelajaran fisika. Pendidik cenderung memberikan pembelajaran fisika dilakukan di kelas daripada dilakukan selain di kelas. Padahal hampir semua mata pelajaran dilakukan di kelas. Siswa akan merasa jenuh jika monoton dilakukan dikelas yang mengakibatkan penyerapan ilmu yang disampaikan pendidik menjadi berkurang, sehingga diperlukan inovasi pembelajaran fisika yang tidak hanya dilakukan di kelas.

Pembelajaran fisika dapat dilakukan dengan berbasis laboratorium sehingga tidak hanya monoton dilakukan di dalam kelas. Laboratoriun dapat menjadi sumber belajar untuk memecahkan berbagai masalah melalui kegiatan praktik, baik itu masalah dalam pembelajaran, masalah akademik, maupun masalah yang terjadi ditengah masyarakat yang membutuhkan penanganan dengan uji laboratorium (Decaprio, 2013). Seperti halnya yang terlihat dalam kurikulum yang dikembangkan saat ini, dimana kegiatan praktikum merupakan alternative untuk memberikan pengalaman belaja kepada siswa (Zahrah, dkk., 2017). Selain itu dengan Laboratorium memberikan kontribusi yang baik pada perkembangan siswa yaitu di atas $50 \%$ pada kompetensi pengetahuan, keterampilan dan membentuk karakter siswa (Nuha, dkk., 2015). Dengan demikian laboratorium sangat penting dalam mengembangkan kemampuan pedagogik siswa.

Model pembelajaran merupakan suatu pendekatan proses belajar tertentu, termasuk tujuannya, langkah-langkahnya, dan sistem pengelolaannya (Arends, 2012, Doyan, dkk., 2015). Model pembelajaran berfungsi untuk menciptakan suasana belajar yang menyenangkan sehingga memotivasi siswa dalam mengikuti pembelajaran (Astutik, dkk., 2016, Doyan, 2015). Model 
pembelajaran adalah kerangka konseptual yang melukiskan prosedur yang sistematis dalam mengorganisasikan pengalaman belajar untuk mencapai tujuan belajar tertentu, dan berfungsi sebagai pedoman bagi para perancang pembelajaran dan para pengajar dalam merencanakan dan melaksanakan aktivitas belajar mengajar (Sutarto dan Indrawati, 2012; Astutik, dkk., 2020). Jadi model pembelajaran merupakan kerangka sistematis yang berisi langkah-langkah pembelajaran dengan menciptakan suasana belajar yang menyenangkan sehingga memotivasi siswa dalam mengikuti pembelajaran untuk mencapai tujuan pembelajaran.

Salah satu faktor yang seringkali dijadikan tolak ukur keberhasilan pendidikan adalah dengan melihat keberhasilan proses belajar-mengajar dalam mencapai tujuannya. Faktor lain yang sangat berperan saat ini adalah motivasi seorang peserta didik dalam rangka mempersiapkan dirinya untuk memulai sebuah proses belajar mengajar. Dalam usaha pencapaian tujuan pendidikan yang diinginkan tentunya banyak sekali metode-metode pembelajaran yang diterapkan pada kancah lingkungan pendidikan terutama bagi pendidikan yang bertujuan untuk meningkatkan motivasi seorang peserta didik. Salah satu langkah untuk memiliki strategi itu dengan cara guru harus menguasai teknik-teknik pengajaran atau metode mengajar (Roestiyah NK,1991:1).

Namun tidak semua metode mengajar yang digunakan itu selalu berdampak positif terhadap pola pembelajaran peserta didik yang kita hadapi karena seperti kita ketahui bahwa setiap peserta didik itu mempunyai karakteristik yang berbeda antara satu dengan yang lainnya. Dalam menentukan metode yang nanti akan kita gunakan hendaknya harus sesuai juga dengan materi yang kita ajarkan karena hal tersebut akan sangat berpengaruh terhadap motivasi belajar seorang peserta didik. Seperti halnya yang diungkap oleh Sutama (2000) tentang peningkatan efektifitas belajar melalui gaya mengajar menyimpulkan bahwa dalam penyampaian materi pelajaran, seorang guru harus bisa menentukan metode apa yang tepat sesuai dengan materi yang akan disampaikan sehingga prestasi belajar siswa akan tercapai sesuai tujuan.

\section{B. Metode Penelitian}

Metode yang digunakan dalam penelitian ini adalah literasi (studi pustaka) dengan mengkaji beberapa sumber yang berkaitan dengan meaningful learning.

\section{Hasil dan Pembahasan}

\section{1) Belajar Menurut Ausubel}

Sebagai bahan ajar terorganisir untuk memfasilitasi struktur psikologi siswa yang berbeda. la mengklaim pembelajaran bermakna lebih mungkin terjadi dibandingakan dengan hafalan, dan hal itu ketika materi yang akan dipelajari kekurangan makna secara logis, siswa kurang memiliki ide-ide yang relevan dalam struktur kognitif, dan individual tidak memiliki seperangkat pembelajaran bermakna (diposisi untuk menghubungkan konsep baru, proposi dan pengetahuan, serta pengalam sebelumnya).

Pada tingkat pertama dalam belajar, informasi dapat dikomunikasikan pada siswa dalam bentuk belajar penerimaan yang menyajikan informasi dalam bentuk final ataupun dalam bentuk belajar penemuan yang mengaharuskan siswa untuk menemukan sendiri sebagian atau seluruh materi yang akan diajarkan. Dalam tingkat kedua, siswa menghubungkan atau mengkaitkan informasi itu pada pengetahuan (berupa konsep atau lainya) yang telah dimilikinya, dalam hal ini terjadi belajar bermakna. Akan tetapi, siswa itu dapat juga hanya mencoba-coba menghafalkan 
informasi baru tanpa menghubungkannya dengan konsep-konsep atau hal lainnya yang ada dalam struktur kognitifnya, maka terjadilah yang disebut dengan belajar hafalan.

Dengan kata lain, belajar akan lebih bermakna jika anak mengalami langsung apa yang dipelajarinya dengan mengaktifkan lebih banyak indera daripada hanya mendengarkan orang/guru menjelaskan materi pembelajaran.

\section{2) Belajar bermakna (Meaningful Learning)}

Inti teori Ausubel tentang ialah belajar bermakna. Bagi Ausubel belajar bermakna merupakan suatu proses dikaitkanya imformasi baru pada konsep-konsep yang relevan yang terdapat dalam struktur kognitif seseorang. Walaupun kita tidak mengetahui mekanisme biologi tentang memori atau disimpannya pengetahuan, kita mengetahui bahwa informasi disimpan di daerah-daerah tertentu dalam otak. Banyak sel otak yang terlibat didalam penyimpanan pengetahuan itu. Dengan berlangsungnya belajar, dihasilkan perubahan-perubahan dalam selsel otak, terutama selsel yang telah menyimpan informasi yang mirip dengan imformasi yang sedang dipelajari.

\section{3) Menerapkan Teori Ausubel dalam mengajar}

Untuk dapat menerapkan teori Ausubel dalam mengajar, sebaiknya kita memperhatikan apa yang dikemukakan oleh Ausubel dalam bukunya yang berjudul Educational Psychology Acognitive View, pernyataan itu berbunyi:

"The most important single factor influencing learning is what the learner already knows. Ascertain this and teach him accordingly" atau yang berarti sebagai berikut: "Faktor terpenting yang memengaruhi belajar ialah apa yang telah diketahui siswa. Yakinilah hal dan ajarilah ia demikian"

Pernyataan Ausubel inilah yang menjadi inti teori belajar. Jadi, agar terjadi proses belajar bermakna, konsep baru atau informasi baru harus dikaitkan dengan konsep-konsep yang telah ada dalam struktur kognitif siswa. Untuk menerapkan teori Ausubel dalam mengajar, selain konsep-konsep yang telah dibahas terdahulu. ada beberapa konsep dan prinsip lain yang perlu diperhatikan. Konsep atau prinsipprinsip itu ialah pengatur awal, diferensiasi, progresif, penyesuaian integratif, dan belajar super-ordinat. Semua konsep ini akan dibahas dengan memberikan contoh penerapanya dalam mengajar

\section{a) Pengaturan awal}

Memperkenalkan konsep pengatur awal dalam teorinya. Pengaturan awal mengarahkan pada siswa kemateri yang akan mereka pelajari dan menolong mereka untuk mengingat kembali informasi yang berhubungan yang dapat digunakan dalam membantu menanamkan pengetahuan baru

\section{b) Diferensiasi Progresif}

Proses penyusunan konsep dengan cara megajarkan konsep yang paling inklusif, kemudian konsep yang inklusif, kemudian konsep kurang inklusif dan terakhir adalah hal-hal yang paling khusus.

\section{c) Belajar Super Ordinat}

Belajar superordinat terjadi apabila konsep-konsep yang telah dipelajari sebelumnya dikenal sebagai unsur-unsur suatu konsep yang lebih luas dan lebih inklusif. Mungkin belajar superordinat tidak bisa terjadi disekolah sebab sebagian besar guru dan buku teks mulai dengan konsep-konsep yang lebih inklusif, tetapi kerap kali mereka gagal untuk 
memperlihatkan secara eksplisit hubungan-hubungan pada konsep-konsep inklusif ini saat dikemudian hari disajikan konsepkonsep khusus sub-ordinat

\section{d) Penyesuaian Integratif}

Untuk mencapai penyesuaian integratif, materi pelajaran hendaknya disusun sedemikian rupa hingga kita menggerakan hierarki-hierarki konseptual "ke atas dan kebawah" selama imformasi disajikan. Kita dapat mulai dengan konsep-konsep paling umum, tetapi kita perlu memperlihatkan bagaimana terkaitnya konsep-konsep sub-ordinat, kemudian bergerak kembali melalui contoh-contoh ke arti-arti baru bagi konsep yang tingkatanya lebih tinggi.

\section{4) Pendekatan Metode Belajar Pembelajaran Bermakna (Meaningful Learning)}

Ada banyak pendekatan atau strategi pembelajaran yang dapat digunakan guru/pendidik untuk menciptakan iklim pembelajaran di kelas yang memungkinkan terjadinya pembelajaran bermakna, antara lain sebagai berikut: a) Terima peserta didik apa adanya. b) Kenali dan bina peserta didik melalui penemuannya terhadap diri sendiri. c) Usahakan sumber belajar yang mungkin dapat diperoleh peserta didik untuk dapat memilih dan menggunakannya. d) Gunakan pendekatan iquiry-discovery. e) Tekankan pentingnya pendekatan diri sendiri dan biarkan peserta didik mengambil tanggung jawab sendiri untuk memenuhi tujuan belajarnya. Belajar pada hakikatnya mengembangkan konstruksi pengetahuan baru sebagai hasil interaksi pengetahuan baru dengan pengetahuan yang sudah ada. Menurut David Ausubel, belajar dengan menerima jauh lebih bermakna daripada belajar dengan menemukan. Dan belajar dengan membangun konstruksi pengetahuan baru lebih bermakna daripada belajar dengan hafalan. Ausubel menegaskan bahwa belajar dengan menerima konten final itu yang seharusnya lebih direkomendasikan di sekolah, tanpa harus menegaskan tentang penerapan model discovery learning. Akan tetapi, pemahaman konsep, prinsip dan ide-ide itu bisa dicapai melalui proses belajar deduktif.

Ada tiga manfaat penting dalam menerapkan pembelajaran bermakna bagi siswa, yaitu: pertama, informasi yang dipelajari secara bermakna lebih lama dapat diingat; kedua, informasiinformasi baru yang dibangun siswa akan memudahkan proses belajar berikutnya untuk materi belajar berkelanjutan; dan, ketiga, informasi yang dilupakan sesudah terbangun struktur pengetahuan baru akan mempermudah proses belajar hal-hal yang mirip walaupun telah terlupakan.

\section{5) Tipe Belajar Menurut Ausubel (Meaningful Learning)}

Empat tipe belajar menurut Ausubel, yaitu: a) Belajar dengan penemuan yang bermakna yaitu mengaitkan pengetahuan yang telah dimilikinya dengan materi pelajaran yang dipelajari itu. Atau sebaliknya, siswa terlebih dahulu menemukan pengetahuannya dari apa yang ia pelajari kemudian pengetahuan baru tersebut ia kaitkan dengan pengetahuan yang sudah ada. b) Belajar dengan penemuan yang tidak bermakna yaitu pelajaran yang dipelajari ditemukan sendiri oleh siswa tanpa mengaitkan pengetahuan yang telah dimilikinya, kemudian dia hafalkan. c) Belajar menerima (ekspositori) yang bermakna yaitu materi pelajaran yang telah tersusun secara logis disampaikan kepada siswa sampai bentuk akhir, kemudian pengetahuan yang baru ia peroleh itu dikaitkan dengan pengetahuan lain yang telah dimiliki. d) Belajar menerima (ekspositori) yang tidak bermakna yaitu materi pelajaran yang telah tersusun secara logis disampaikan kepada siswa sampai bentuk akhir, kemudian pengetahuan yang baru ia peroleh itu dihafalkan tanpa mengkaitkannya dengan pengetahuan lain yang telah ia miliki.

6) Langkah-langkah Belajar Metode (Meaningful Learning) Bermakna Menurut Ausubel. 
Cara Pembelajaran Bermakna dengan Menggunakan Peta Konsep :

a) Pilih suatu bacaan dari buku pelajaran.

b) Tentukan konsep-konsep yang relevan.

c) Urutkan konsep-konsep dari yang paling inklusif ke yang paling tidak inklusif atau contohcontoh.

d) Susun konsep-konsep tersebut di atas kertas mulai dari konsep yang paling inklusif di puncak konsep ke konsep yang tidak inklusif di bawah.

e) Hubungkan konsep-konsep ini dengan kata-kata penghubung sehingga menjadi sebuah peta konsep.

Langkah-langkah yang dilakukan guru untuk menerapkan belajar bermakna Ausubel adalah sebagai berikut: advance organizer, progressive differensial, integrative reconciliation, dan consolidation. Advance organizer merupakan pola interaksi siswa dengan guru di dalam kelas yang menyangkut strategi, pendekatan, metode, dan teknik pembelajaran yang diterapkan dalam pelaksanaan kegiatan belajar mengajar di kelas. Model pembelajaran disusun untuk mengarahkan belajar, dimana guru membantu siswa untuk memperoleh informasi, ide keterampilan, nilai, cara berpikir dan mengekspresikan dirinya.

\section{Kesimpulan dan Saran}

\section{1) Kesimpulan}

Pembelajaran Meaningful Learning merupakan suatu konsep belajar dimana guru menghadirkan situasi dunia nyata ke dalam kelas dan mendorong siswa membuat hubungan antara pengetahuan yang dimilikinya dengan penerapannya dalam kehidupan mereka sebagai anggota keluarga dan masyarakat.

Tugas guru dalam pembelajaran Meaningful Learning adalah memberikan kemudahan belajar kepada peserta didik, dengan menyediakan berbagai sarana dan sumber belajar yang memadai. Guru bukan hanya menyampaikan materi pembelajaran yang berupa hapalan, tetapi mengatur lingkungan dan strategi pembelajaran yang memungkinkan peserta didik belajar.

\section{2) Saran}

Guru harus dapat menyajikan dunia nyata atau benda-benda konkret saat pembelajaran sehingga siswa dapat membuat hubungan antara pengetahuan yang diperolehnya dengan penerapannya dalam kehidupan sehari-hari, agar tujuan pembelajaran yang diharapkan dapat tercapai.

\section{E. Daftar Pustaka}

Decaprio, R. 2013. Tips Mengelola Laboratorium Sekolah. Yogyakarta: Diva Press.

Dahar, Ratna Wilis,Teori-Teori Belajar Dan Pembelajaran. Bandung: Erlangga

Kuswana, Wowo sunaryo.2014.Taksonomi Kognitif.Bandung: PT. Remaja Rosdakarya

Nuha, D.F, Haryono, \& Mulyani, B. 2015. Kontribusi laboratorium terhadap pembelajaran Kimia SMA. Jurnal Pendidikan Kimia, 4(1):82-88.

O’Malley, J. \& Pierce, L.V. 2015. Authentic Assessment for English Language Learners: Practical Approaches for Teachers. New York: Addison-Wesley Publishing Company.

Yuwentin, O., Mahardika, I.K., Nuriman, Sudiatmika, A.A.I.A.R., \& Sugiartana, I.W. 2020. The development of think together about science in society (TTOSS) learning model to increase critical thinking skill in science lesson. Prosiding Journal of Physics: Conference Series, 1465(1):12042-1 s/d 12042-5. 
Zahrah, F., Halim, A., \& Hasan, M. 2017. Penerapan praktikum dengan model problem based learning (PBL) pada materi laju reaksi di SMA Negeri 1 Lembah Seulawah. Jurnal Pendidikan Sains Indonesia (Indonesian Journal of Science Education), 5(2):115-123 